\title{
The Europeanisation of German ethnic identities: the case of German and Turkish students in two Stuttgart secondary schools
}

\author{
Daniel Faas \\ University of Cambridge, UK
}

\begin{abstract}
Germany's national (or ethnic) identity has become thoroughly European and there are even signs of Eurocentrism. This is particularly problematic for the Turkish Muslims who, arguably, are not European. This article explores how fifteen-year-old German and Turkish youth in two Stuttgart secondary schools, one in a predominantly working-class area (Tannberg Hauptschule) and the other in a more middle-class environment (Goethe Gymnasium), negotiate their identities. Drawing on documentary sources, focus groups and semi-structured interviews, the research found that at Tannberg, which at times adopted a Eurocentric approach and where some teachers were getting close to being Islamophobic, young people developed ethno-national identities. In contrast, at Goethe, which promoted European values alongside rather than instead of multicultural values, young people employed national-European hybrid identities. This article raises important questions about the role of education in the development of identities, and how to address notions of cultural insensitivity and inequality.
\end{abstract}

\section{Introduction}

Germany has struggled to include minority ethnic communities like the Turkish Muslims into its Europeanised concept of nationhood. In the first three decades following World War Two (1945-1973), successive German governments employed the concept of Europe as an identity and quickly developed an idealistic relationship with Europe (Goetz, 1996; Katzenstein, 1997). As a founding member of both the European Coal and Steel Community in 1951 and the European Economic Community in 1958, the government redefined Germany's national (or ethnic) identity, shattered by the war, in European terms (Risse \& Engelmann-Martin, 2002). At the same time, policymakers and politicians adopted a pragmatic approach to multiculturalism and recruited millions of so-called guest workers (Gastarbeiter) to help rebuild the German 
economy (Bade, 1993, 2000). The 31 October 1961 bilateral agreement between Germany and Turkey, which Şen and Goldberg $(1994$, p. 10) referred to as 'one of the most important milestones in the history of German-Turkish relations', stated that Turkish workers should return to their home country within two years. Integrating 'guest worker children' into the German school system while preparing them for a possible return to their country of origin, known as 'foreigner pedagogy' (Ausländerpädagogik), was the guiding principle of education, particularly in the 1960s and early 1970s (Hoff, 1995; Luchtenberg, 1997).

A shift in the relationship between national, European and multicultural agendas was brought about by the 1973 Arab oil crisis which prompted the Social Democratic government under Chancellor Brandt to put a hold on the further recruitment of guest workers. The image of immigrants was transformed from being a welcome pool of cheap labour into a threat to jobs, a drain on the welfare state. They were thus unwanted 'foreigners'. Politicians adopted an increasingly reluctant and hostile approach to multiculturalism and passed legislation promoting the return of guest workers to their country of origin. For example, under the 1983 law for the 'Promotion of Readiness to Return' (Rückkehrförderungsgesetz), every guest worker who voluntarily left Germany received an incentive of 10,500 deutschmarks $(£ 3,500)$, but only about 250,000 migrants, particularly those of Turkish origin, responded to this opportunity (Santel \& Weber, 2000). Whilst the national and multicultural agendas were perceived as incompatible at the time, politicians remained ardent proponents of a politically integrated Europe. Europe became a focal point for national political identities in German schools. As early as 1978, attempts were made to include a European dimension in schools (Kultusministerkonferenz, 1990). ${ }^{1}$ Several German federal states (such as Baden-Württemberg) subsequently overhauled their curricula to implement a European dimension. This highlighted the role of education in shifting German national identities towards a more European agenda.

More recently (since 1998), Germany has seen a shift from notions of 'foreigner politics' (Ausländerpolitik) to a concept of 'integration politics' (Integrationspolitik), including the political acknowledgement that Germany is a multicultural society; the reform of the citizenship law (Schiffauer, 2006); ${ }^{2}$ the new immigration law which provides for integration courses; the new anti-discrimination law (which punishes discrimination based on race, ethnic origin, age, sex, disability, religion or sexual orientation); and the first integration summit, hosted in July 2006. Despite a less restrictive and exclusive approach to multiculturalism at the national political level, several mainly conservative-led federal states have continued to deploy a distinction between 'us' (Germans) and 'them' (non-Germans). For example, the federal state of Baden-Württemberg introduced a law banning teachers from wearing headscarves (Landesinstitut für Schulentwicklung, 2006) and, in 2006, also introduced a 'citizenship test for Muslims' (Erdenir, 2006) including questions about a person's views on forced marriage, homosexuality and women's rights. National identification has continued to be ambivalent in Germany in recent years as we can see from the debates around national pride (Nationalstolz), initiated by senior conservative politicians (e.g. the Christian Democrats) in 2001 (Rippert, 2001). ${ }^{3}$ Schools have continued to privilege European agendas over and above multicultural and 
anti-racist education (interkulturelle Erziehung), thus indicating that the conflict of combining Germany's Europeanised national identity with the multicultural political and educational agenda has not yet been resolved. This brief socio-historical account of the Europeanisation of German ethnic identities sets the context for an analysis of schools and students. Residues of these macro-level policy approaches can still be found in schools today.

The aim of this article is to show how two secondary schools in Stuttgart attempted to make sense of these macro-political agendas and to analyse how, in these contexts, different groups of young people negotiate their identities. Whilst the data I draw upon derive from a larger study designed to explore how German and English national agendas are reshaped by European and multicultural agendas at government level and what consequences these triple agendas have for the political identities of youth (Faas, 2007, forthcoming), this article focuses on students in the two German schools. I decided to compare two types of secondary schools, one in a mainly working-class environment and the other in a more middle-class area. I also chose to compare German ${ }^{4}$ and Turkish youth, an ethnic group which arguably is not European. Although the Turks have been studied for quite some time in Germany (e.g. Auernheimer, 1990; Faist, 1993; Şen \& Goldberg, 1994; Gallo et al. 2002; Şen, 2002), research in the sociology of education has hitherto not explored the complexity of factors affecting their identities.

\section{Research methodology}

The research was informed by the insights offered by post-structuralist theory, particularly notions of a fragmented society in which identities were seen as being fluid (e.g. Hall, 1992; Mac an Ghaill, 1999; Rassool, 1999; Tizard \& Phoenix, 2002). The advantages of a post-structuralist approach to the study of identity were that it opened up the possibility of a non-unitary subject with multidimensional identities and also reflected the shifting nature of society. Crucially, in a post-structuralist framework, identities are not fixed, static and of a binary nature (e.g. white/black) but discursively negotiated and renegotiated. The notion of performativity (Butler, 1997) was particularly important for the design of the broader study because performative suggests that ethnic and political identities are a continual establishment and articulation of binaries. The linking of techniques of the self (Foucault, 1988) and performance opens up an exploration of the ways in which the social context mediates how subjects deal with the lived realities of specific institutional locations (Mac an Ghaill, 1999).

The concept of identity/identities, meaning the communities young people felt they belong to, was also crucial for the conceptualisation of this study. In contrast, the notion of identification (Skeggs, 1997) refers to the reasons and discourses students employed to identify with a particular community (e.g. Europe). It is also important to differentiate between hybrid (e.g. Hall, 1992; Mercer, 2000; Tizard \& Phoenix, 2002) and hyphenated identities (e.g. Caglar, 1997). Hybrid identities, according to Bhabha (1990), can be understood as 'mixed' identities

which emerge as a result of the interconnections between diasporic or ethnic affiliations and political identities such as 'being European'. In contrast, the notion of hyphenated identities, as understood by Caglar (1997), relates more to territorial or political identities, such as African 
American, rather than the emergence of a new identity. It is hard to know whether the young people in this study developed hybrid or hyphenated identities. However, the fact that many young people constructed their identities along ethnic and political dimensions, rather than mediating between two territories, suggests that the notion of hybrid identities is perhaps more accurate when analysing contemporary youth identities.

For the broader study, conducted during the first half of 2004, I distributed a questionnaire to about 100 students in each school. The aim was to obtain broad insights into how students positioned themselves in relation to ethnic and political identities. Whilst the questionnaire revealed some attitudinal differences regarding Europe and the nation-state, it was not clear what students actually meant by 'being German', 'Turkish' or 'European' and how they negotiated their identities. This is why most of the data I collected in each school were of a qualitative nature. Regarding the focus group and semi-structured individual student interviews, I worked with the teachers in the schools to recruit appropriate groups in terms of gender, ethnicity and friendships. I told teachers to help me identify students who could express themselves sufficiently well in German/English to answer my questions. This meant of course that I did not tap the opinions of the introverted, passive or shy students. However, I asked for students from all ability groups to be included in the sample. In the event, I conducted six focus groups of four to five students in each school (single-sex and mixed German and Turkish students) and I also interviewed eight students in each school (two German boys and two German girls and, similarly, two Turkish boys and two Turkish girls). The main reason for interviewing German and Turkish students separately was that in an ethnically mixed group the voices of Turkish students may not have been heard and there would have been no possibility of tapping the different discourses German and Turkish students employed in their identity formation processes. Additional interviews were conducted with the head, citizenship coordinator, head of geography and head of religious education to gain insights into the role schools play in shaping identities.

In this article, I focus my discussion on fifteen-year-old native youth and youth of Turkish origin in two schools in an inner-city Stuttgart borough. A majority of students $(56.8 \%)$ in Tannberg Hauptschule (a vocational-track school) have skilled and unskilled parents. In contrast, a majority of students (54.2\%) in Goethe Gymnasium (a university-track school) have professional middle-class and routine nonmanual parents, underlining the middle-class character of this school. It should be noted, however, that more than one quarter of Turkish students at Goethe (28.6\%) have skilled and unskilled parents compared with just one German student, and nearly seven out of ten German students have professional middle-class and routine non-manual parents compared with one-third of Turkish students. This not only indicates that the Turkish sample at Goethe is somewhat 'less middle class' than the German sample but, more importantly, it lends further weight to the importance of schooling over and above other factors with regard to identity formation. Table 1 summarises the school profiles. 
Table 1. A summary of the school profiles of the two Stuttgart secondary schools

\begin{tabular}{|c|c|c|}
\hline & Tannberg Hauptschule & Goethe Gymnasium \\
\hline School population & $\begin{array}{l}320 \text { students } \\
18 \% \text { Turkish }\end{array}$ & $\begin{array}{l}564 \text { students } \\
5 \% \text { Turkish }\end{array}$ \\
\hline Location & Working-class inner-city & Middle-class inner-city \\
\hline Citizenship issues & $\begin{array}{l}\text { Discrete subject, } \\
1 \text { hour per week }\end{array}$ & $\begin{array}{l}\text { Discrete subject, } \\
2 \text { hours per week }\end{array}$ \\
\hline Multicultural issues & Turkish mother-tongue teaching & Intercultural tolerance, displays \\
\hline $\begin{array}{l}\text { European issues } \\
\text { (a) Languages } \\
\text { (b) Geography and } \\
\text { history }\end{array}$ & $\begin{array}{l}\text { English only } \\
\text { Entire Year } 7 \text { geography, } \\
\text { half of Year } 6 \text { history }\end{array}$ & $\begin{array}{l}\text { English, French, Italian } \\
\text { Entire Year } 6 \text { geography, } \\
\text { half of Year } 7 \text { history }\end{array}$ \\
\hline School approach & Eurocentric Education & Multicultural Europeanness \\
\hline
\end{tabular}

Following the national pattern, the two schools were trying to promote Europe over and above cultural diversity and national identifications, albeit with different emphases. Despite the fact that the school system is under the direct control of the regional government, schools and teachers could make a difference regarding the ways in which they interpreted and delivered the mandatory curriculum. The different school approaches affected the identity formation processes of German and Turkish youth in the study, as we shall see further below.

Although there had been a controversy in the past over the building of a new mosque in the catchment area of Tannberg Hauptschule, there did not seem to be any conflict or gang fights between resident communities. The city of Stuttgart also seemed to have been spared the sorts of violent disputes between first-generation parents (representing what I would call 'traditional Turks' wearing a headscarf) and second-generation Turkish girls (representing what I would refer to as 'westernised liberal Turks') in Berlin, where six young Turkish women were killed by family members between October 2004 and February 2005. The latter was also more the type of Turkish student I felt I encountered in both Stuttgart secondary schools, particularly at Goethe Gymnasium, as hardly any of the girls wore the hijab and all dressed in a very western way, wearing jeans and trainers. Only one Turkish boy at Goethe, who described himself as a German Turk, signalled his Turkishness by wearing red jumpers and a necklace in the shape of the moon star on the Turkish flag. The relatively congenial community relations outside the schools could partly be the result of Stuttgart's successful local integration policy called 'the Pact for Integration' (Bündnis für Integration) which was adopted by the city council in 2001 (Landeshauptstadt Stuttgart, 2001). The Pact for Integration is a coalition between politics and administration in the public sector; special interest groups and businesses in the private sector; and associations, sport clubs, community groups, and non-governmental organisations 
representing civil society. In the past few years, whilst promoting diversity, Stuttgart has been keen to integrate all people on the basis of common German language. Nevertheless, the identity formation processes of students were rather different, and shaped by the school dynamics of mediating and interpreting macro-level policies and curricula.

\title{
Eurocentric education and ethno-national identities
}

Tannberg Hauptschule, located in a predominantly working-class residential area of Stuttgart, mediated national and citizenship agendas through a dominantly European and arguably, at times, a Eurocentric (i.e. white Christian) approach. Whilst civic education texts emphasised the federal democratic structure of Germany (e.g. local political decisions, political participation and democratic culture in Germany), the European dimension was privileged over and above national and multicultural agendas in curriculum subjects such as geography and history. For example, in geography, Year 7 (ages 12 to 13) spent the entire year looking at Europe and students were given a geopolitical overview of Europe before they studied either France or Britain, the physical and human geography of northern Europe, Mediterranean countries as well as the changing landscape of Europe. In Year 9 (ages 14 to 15), Europe was one of five crosscurricular themes of the Hauptschule curriculum, with one further geographical teaching unit on the European Union (EU). Mr Koch, the citizenship coordinator, maintained that there was no alternative to the European dimension and that it was essential to deal with Europe in school:

\begin{abstract}
DF: Citizenship should include experiencing the European dimension. What do you make of that?

Mr Koch: Must, must; not should. The curriculum must have a European dimension. We are living in a united Europe, a multicultural society, especially here at this school and the European spirit must be promoted stronger than ever before. There is no alternative to that. The only problem we have is that we do everything on a theoretical level. For example, it's very problematic when I visit Strasbourg with my Turkish students; they need a visa. Same problem occurs when I want to travel to England; I have a lot of trouble at the border. That shouldn't be the case in a united Europe; all countries should have the same rules. But it's absolutely necessary to deal with Europe in school.
\end{abstract}

Despite some intercultural teaching, the teachers I interviewed seemed to struggle to combine the notion of multiculturalism with the dominant European agenda. For example, while eating with the students in the canteen, I witnessed cultural insensitivity amongst some Tannberg Hauptschule teachers towards Turkish Muslim students (although these might not necessarily be their espoused values). On that particular day, there was pork and beef sauce available for the students and the teachers on duty told a male German student who wanted to help himself to some beef sauce that this is 'Muslim sauce' (Moslemsoße) and that he should rather take some 'non-Muslim sauce' and when the German student asked why he shouldn't eat beef sauce the supervising teacher replied that 'you will get impotent from that'. I also sat in some lessons 
where teachers occasionally spoke German with a foreign accent (Ausländerdeutsch). These examples indicated how some teachers marginalized minority ethnic students.

Although there was no obvious hostility towards Turkish students at Tannberg Hauptschule, there were other suggestions that Turkish people were still considered strangers and not part of the European project. For example, Miss Klein (the head of religious education) referred to the white Christian roots of Germany and Europe and established a racial/religious hierarchy which privileged the Christian cross over the Muslim hijab. She also showed little understanding for the dilemma Muslim teachers faced in German schools:

DF: How do you feel about wearing headscarves or crosses in school?

Ms Klein: I think that we are still Christian Occidental [i.e. white and European] here with our basic values. I am of the opinion that if a religious symbol was allowed in class then it should be the cross. Islam, for me, has both a religious and political dimension and I'm not allowed to wear the cross in a Muslim context. Then why should we allow things, despite being a democracy, that are not possible in other countries either. I mean, I can only argue from my religious viewpoint. When children wear the headscarf I have no problem with that but I think that as a teacher I have a political function. As our constitution demands neutrality, and teachers are meant to be role models, I cannot accept that. And if teachers were allowed to show their religious-political background, then it should be the cross and not the headscarf.

Arguably, the Eurocentric approach of some of the teachers and the predominantly workingclass background of Tannberg students made it very difficult for both German and Turkish students to relate positively to Europe as a political identity. Despite having some knowledge about Europe and being able to talk about Germany's role in Europe and the possibilities of a Turkish EU membership, neither the German nor the Turkish students I interviewed saw themselves as 'European'. Europeanness, for these students, was not separate from the concept of being German-'being German', in other words, equals 'being European'. Most of the Turkish students I interviewed argued that they felt European only 'because I live here in Germany ... we are Germans and Germany is part of the EU'. In contrast, each of the four Turkish boys in one focus group claimed that 'I don't think I feel part of Europe ... I feel more Turkish'. Similarly, the majority of German working-class students I interviewed at Tannberg Hauptschule also only felt European 'because Germany is part of the EU and Europe'. One group of students, for example, argued that 'if you go to a foreign country and you say that you are European and not German, you are perhaps treated a bit better'. This remark can only be understood in the light of Germany's particular history of the Third Reich and the subsequently ambivalent relationship with its past and national identity we saw in the opening part. A small minority of respondents felt rather proud about their German identity, saying, 'I feel German; I don't know what all these countries have in common'.

In contrast, most Turkish interviewees seemed to identify with Germany. Most claimed that Germany was more important than Turkey. It was fascinating to listen to the ways in which the 
group of Turkish girls balanced their identities. The following quotation shows the dilemma Sema and Zerrin face as a result of their hybridised ethno-national (i.e. Turkish German) identities. In Germany, they are positioned as 'foreigners' and in Turkey people refer to them as Germans, which is precisely what Boos-Nünning (1986) called a 'reference group problem' and what Auernheimer (1990, p. 201) referred to as individuals acquiring a marginal identity and positioning in relation to both cultures of reference:

DF: Where do you feel you belong to?

Sema: As a citizen I feel I belong to Germany. But when people ask me, I mean when I am here then people call me 'foreigner'. When I go to Turkey, they call me 'German' there.

Zerrin: Yes, I don't feel I belong to anything. I don't think that I am German and I don't think that I am Turkish. I don't know. When I go to Turkey, then they say 'Oh, look at the German'; and here I am a foreigner. Great. So, who am I? Where do I belong to?

Sema: As a citizen, I can say I belong to Germany.

Zerrin: I can say that I'm a German citizen but I'm not German. German citizen, I think, means that I have to adapt to this country, I try to adapt myself, and then I think about the laws and everything. I know a lot more about Germany so that I am a German citizen, but I'm not German. But, I'm not Turkish either.

Sema: I know Germany better than Turkey. I could never ever imagine living in Turkey.

Zerrin's questions 'Who am I?' and 'Where do I belong to?' highlight the ongoing process of identity formation, the struggle between 'being a German citizen', which is based on residence and 'being German', which is based on blood and 'race'. During the course of the conversation, Sema further justified her feelings, saying that she could not speak Turkish that well and that she did not have any friends back in Turkey. Also, she preferred the freedom of western societies to dress however you want and distanced herself from those 'typically Turkish women who just sit around all day long not doing much apart from knitting and gossiping about others' (i.e. the traditional Turk). Clearly, Sema, but also Zerrin and others from cities such as Antalya or Istanbul, rejected this traditional Muslim image of women, which is particularly strong in the rural villages of the southeast Anatolia region bordering on Syria and Iraq. This partly accounts for why Sema and Zerrin did not strongly identify with Turkey.

Other Turkish interviewees also had hybrid identities. For example, the group of Turkish boys argued that they felt slightly more Turkish than German because 'although we were born in Germany, our origin and family background is in Turkey'. However, their struggle for social acceptance was also highlighted in the experience that 'here [in Germany] we're foreigners and in Turkey we are also foreigners, basically we're foreigners everywhere'. Arguably, the tendency that some boys identified more strongly with Turkey than girls might have to do with their different roles in the Turkish society, where women often have a more domestic role while men carry on their family name, and thus their honour and identity.

Such multidimensional and hybrid identities have also been discussed by authors such as Caglar (1997), who argued that, although hybridisation ascribes cultures and identities with 
fluidity, they remain anchored in territorial ideas, whether national or supranational. Hybridisation limits the heterogeneity of German Turks' cultural formations to two cultural wholes-namely, to Turkish and German culture. Hence, the 'sources of diversity' (e.g. local, regional, national, supranational identities) are pre-given rather than being practice-bound. These theoretical weaknesses, Caglar maintained, make it difficult to celebrate hybridity as a real break from essentialist notions of culture. Instead of breaking with the basic tool of constructing the 'Other', hybridisation is another means by which mixture is inscribed as essence (ibid., pp. 172ff.). Whilst hybridisation produced a third space allowing other identities to emerge (e.g. Turkish German), there is some evidence in this student data that 'the language of binary oppositions [i.e. German or Turk]' (Hall, 1992) has evolved into one of tertiary oppositions (i.e. German or Turk or German Turk) which also constructs, for instance, the German Turks as 'Other'.

While the group of Turkish students constructed their identities around ethnonational (Turkish and German) communities, they could not easily relate to the regional Swabian identity because of their unfamiliarity with the Swabian dialect, customs and traditions. Swabia was an administrative region and is today still used in popular culture as an ethnic identity for those living in the Württemberg part of the federal state of Baden-Württemberg, including Stuttgart. However, as a result of being born in Stuttgart, some Turkish students, notably the group of Turkish girls, were able to imitate the Swabian dialect fairly well, saying 'Ah, des koscht du jetzt net mache, gel' (Oh, you can't do this now, can you?). The use of the word 'gel' in this sentence was particularly suggestive of the girls' familiarity with the Swabian dialect. Generally, however, Turkish interviewees at Tannberg argued that 'I feel more part of Stuttgart than BadenWürttemberg'. For young Turkish people who were born in Stuttgart, but not fully exposed to the Swabian culture, this was a rather distant community.

The notion of 'being Swabian' was then linked by some of the native German respondents with concepts of blood and family which, arguably, made it very difficult for the group of Turkish students to relate to as their families were born in Turkey. The following passages, taken from individual interviews with two German students, show that Ralf and Verena privileged their Swabian identity over their German identity:

DF: To what extent do you see yourself as Swabian or German?

Ralf: Swabian, rather Swabian, yes. Because there are also those in the East and I am rather Swabian. My mum was born here, and my dad, and me too and we are totally a Swabian family, yes.

Verena: I was born and grew up in Stuttgart, in Baden-Württemberg, and when I was younger I always spent the day at my grandma's place, cos my mum was at work, and she raised me like a Swabian, so.

However, there were also those German interviewees, such as Sebastian, who argued that 'I feel first German and then Swabian, I have a German passport and not a Swabian one'. Despite varying emphases on local, regional and national identities, what emerges from these data is 
that most of the German youth in Tannberg Hauptschule employed ethno-national (i.e. Swabian German) identities, indicating the complex nature of young people's identities.

\section{Inclusive education and national-European identities}

Turning now to Goethe Gymnasium, located in a predominantly middle-class area, we can see that the school also promoted European values, but this time alongside rather than instead of multicultural values. The school prospectus states that:

The ethos of our school is characterised by mutual respect, confidence and tolerance towards other people. Our students, which come from diverse backgrounds, practice intercultural tolerance and community; they learn the manifoldness of European languages, cultures and mentalities and can thus develop their own identity within our school. The internationality of our school community alongside its location next to libraries, museums, opera houses, archives, theatres and galleries characterise our profile. Europe as a cultural area is one of our guiding principles.

European and multicultural values also figured prominently in the curriculum of subjects such as geography and history at Goethe. For example, in geography, three out of four teaching units in Year 6 (ages 11 to 12) were spent on Europe, with students studying the orientation in central Europe, the continent of Europe and European integration. The entire Year 8 (ages 13 to 14) dealt with global and multicultural geographical issues including India and China, Japan, the United States, and the Muslim world. In history, for half of Year 7 (ages 12 to 13) and the entire Year 8 (ages 14 to 15), the curriculum taught students about medieval Europe, absolutism in Europe, and the Greeks and Romans. Only some of the Year 10 teaching units explicitly dealt with German national agendas, including World War Two and National Socialism. Goethe Gymnasium delivered the mandatory curriculum but in its own unique way, through the promotion of European and multicultural dimensions.

In contrast, the teachers I interviewed had a deeply ambivalent relationship towards German national identity and referred to Germany's Europeanised national identity. This submerged national identity was reflected in the school's approach of 'multicultural Europeanness' which emphasised Europe as a common bond but, at the same time, allowed individuals to keep their cultural and ethnic identities. Following the national political pattern, Miss Fischer (the school's headmistress) promoted Europeanness rather than German ethnic identities:

DF: What kind of national identity should the curriculum promote?

Ms Fischer: Well, we Germans have difficulties with our identity, much greater difficulties than other European countries because of our past, the Third Reich, and insofar we're actually born to be Europeans because our national identity is

very subordinate. Right-wing extremists don't like that and what's worrying me is that some young people are supporting extremist ideas. Therefore, l'd say that young people are looking for certain rules, role models and a national consciousness because otherwise they 
wouldn't support that. Young people have an interest in the German past including the Third Reich but they don't show a feeling of guilt and remorse any longer; they just see it as a part of history like Bismarck. They want to know about World War Two and find it horrible but it's the past for them ... I feel European anyway and I don't feel German. I am only aware of my German nationality when I'm abroad sometimes.

The head of religious education, Miss Weber, also had an ambivalent relationship towards German national identity, arguing that, in her lessons, the national element was always underdeveloped. 'I have no access to any national values and when I hear that word I've already got a problem with it. But international or general cultural values play an important role in my lessons'. She argued that she is German just because she speaks German and her parents were born in Germany. But apart from that, Miss Weber, like the headmistress, was not particularly interested in German identities and promoted Europe. However, some teachers at Goethe admitted that it is difficult to 'teach' a sense of European identity, arguing that travelling, school partnerships and exchanges, as well as modern foreign language learning, helped students develop a sense of European identity. Whilst young people at Goethe Gymnasium had access to all these European activities because of their privileged socio-economic background, students at Tannberg Hauptschule were largely deprived of such opportunities.

Arguably, the fact that Goethe Gymnasium mediated ethno-religious and cultural differences through notions of tolerance, liberalism and a strong sense of community helped students to learn more about other cultures and to make contact with students from different backgrounds. As a result, there were few signs of any ethnic tensions within the school community. Both German and Turkish fifteen-year-olds reported only isolated discriminatory incidents. For instance, Sema argued that 'I've recently heard from my teacher that Turks always have cleaning jobs and that's really hurt me; and then the headscarf is the next problem'. Sema's remarks not only revealed the ways in which some teachers positioned Turkish youth as inferior to Germans, but also alluded to the German debate about whether or not headscarves should be allowed in public institutions. Both Maximilian and Alexander maintained that there were some teachers at the school who disliked other nationalities and gave better marks to Germans. Generally, however, the dynamics between teachers and students, as well as amongst students, were far from being conflictual and Goethe Gymnasium's liberal and progressive approach earned them considerable local media coverage as a model for overcoming ethnic differences and raising intercultural tolerance. By contrast, a number of Turkish interviewees felt subject to discrimination and prejudice outside Goethe Gymnasium, much of which revolved around verbal abuse (e.g. foreigners, potato, sexist remarks) and cultural insensitivities (e.g. wearing of headscarves, gender roles in the Turkish society). Some of the German students at Goethe also provided accounts of prejudicial experiences they had had outside school. However, their discriminatory experiences were linked to issues of social class and gender rather than ethnicity.

The culturally tolerant school atmosphere and the inclusive approach of 'multicultural Europeanness' shaped German and Turkish students' political discourses and identity 
formations. Unlike at Tannberg, where young people preferred national governments, a majority of both German and Turkish respondents argued for more European integration (e.g. 'national laws would be subordinated to the European Constitution which would be good'). Nerhim (a Turkish girl) alluded to the notion of a European Family, which Sir Winston Churchill powerfully described in his September 1946 speech at Zürich University about the place of Europe within the world concept of the United Nations. The following passage highlights the generally pro-European discourses of these students:

Nerhim: Well, I find the EU, the unification of all these countries, a good thing. It's just the same within a family; for example, when you have a problem then you discuss that amongst four or five people and so; and I find it good that Europe is doing the same generally speaking. ... Europe is like a family; they gather and debate what could be improved and that's really good.

Lena: I think that this would result in a state where one has the power, is rich, and I find that a good idea.

Anna: If we get thrown into one party, it has to be the same everywhere. It would resolve some problems.

These findings were corroborated by the fact that in the survey, a majority of German and Turkish respondents preferred seven political issues to be dealt with on a European level and only three areas (justice, employment and family) by the German government. In particular, both groups thought that global political issues (e.g. peacekeeping, terrorism, Third World, equal opportunities, pollution) should be dealt with by European institutions, whereas 'family' and 'employment' -in other words, more national political issues-should be dealt with in Berlin. The sample of Goethe students also had higher average scores (77.3\%) when asked to locate ten countries correctly on a geographical map of Europe than their counterparts at Tannberg (62.6\%). Their privileged backgrounds allowed them to take part in European exchanges and to travel across Europe and thus benefit from the opportunities associated with Europe. Arguably, the relatively high scores of youth in both institutions were a result of the schools' emphasis on Europeanness rather than German values as well as Germany's generally pro-European political approach, discussed earlier. Although native youth had a slightly higher average score (77.7\%) than youth of Turkish descent $(72.8 \%)$, the fact that this was not statistically significant was an indication of Turkish students' familiarity with Europe, their positioning within national-European discourses and the knowledge they had gained from being educated at a Gymnasium which promoted European (and multicultural) values.

Although the school's interpretation of 'Europeanness' to include multiculturalism clearly encouraged the students to relate positively to Europe, to construct a European political identity, most Turkish and German students made identification with Europe dependent on stays abroad (e.g. 'I only know Germany; if I was living in Spain for a few years, then I'd more say that I'm European cos I'd be familiar with different countries'), parental influence (e.g. 'my parents experienced a lot and tell me a lot about other countries and cultures; Europe plays an 
important role for me too cos I'm interested in getting to know these other countries'), and the school curriculum (e.g. 'we learn a lot of European languages here in school and talking in Italian, English and French to other people makes me feel partly European'). The following excerpts indicate that fifteen-year-olds felt positive about Europe:

DF: To what extent do you see yourself as European?

Ali: Erm, of course I'm European. Europe is very big and is getting bigger and bigger. And when Turkey joins the EU it'll be even bigger. Europe is getting more and more important to me cos of Turkey. ...

Samuel: Europe, the EU, plays an important role in my life. When I go abroad it's just so simple. There are hardly any border controls and it's just getting easier and easier. The countries are not on their own anymore and are together; and there are no borders anymore, very open. ...

Mariam: I feel European because of the Euro. The Euro impacts on your life. I mean, in the newspaper they always talk about the Euro, Eurozone, Europe and so and l've noticed that the countries are getting closer and closer and not every country has its own policy. And the economy has grown together too. And you can travel to other countries without any problems at the borders.

Several German students employed the image of a chain of identities, arguing that Stuttgart, Germany and Europe were all interlinked and thus sites for identity formation. In particular, the group of German boys thought that 'yes, we live in Europe; Stuttgart and Germany are part of Europe so I also feel partly European. But the Italians, English are all Europeans too. So, if I said I was only European [rather than European German or German European] then people might think I'm Polish or so'. However, there was no evidence in the data that young people felt European-only or that they privileged Europeanness over national identities.

Instead, whilst Europe was part of young people's multidimensional and hybrid identities at Goethe, a majority of Turkish students I interviewed emphasised their German identities over and above Turkishness. They based their national identification upon notions of birth and residence. Zeynep (a Turkish girl) thought that 'I'd say more German than Turkish. My dad works here, I plan to study here after school and work here as well' and Nilgün (another Turkish girl) also prioritised her German identity, saying that 'I was born here and that's why I feel more German'. Melik's remark in the following excerpt-that he feels like a Turkish Stuttgarter, a German- European Turk or a Turkish German-was suggestive of the multidimensional and hybrid nature of young people's identities at Goethe:

DF: Where do you feel you belong to?

Melik: I feel as a Turkish Stuttgarter so to speak, a German-European Turk or a Turkish German, but not Swabian. I don't know the Swabian culture and, I think, I'd have to be German for that with my ancestors being Swabians too. 
Nurhan: You'd have to experience the culture at home but we can only see our Turkish culture and, I mean, I wouldn't want to lose that. I don't really know the Swabian way of life. Sometimes, teachers make Swabian jokes and stuff.

Ismet: (imitating the Swabian dialect) Gel.

Nurhan: We don't really know much Swabian stuff.

Ismet: I'd like to add that I don't see myself as a Swabian either, more as a Stuttgarter. It's also easier to get to know the German culture, just here generally by living here, but the Swabian culture is more at home and I'm not around that. Sometimes I don't really know whether something is particularly Swabian.

Nurhan: Perhaps Stuttgart is the Swabian world and it appears to me like a German world but maybe I don't fully grasp the contrast; I should go to Berlin or so for a while and see what the differences are.

Many native German students (whilst also feeling partly European) emphasised local and regional identities whilst problematising the notion of a German national identity, arguing 'the only point when I'd feel German is when I speak the German language, my mother tongue. I wouldn't say I'm proud of my country which has to do with the past. If you said "you're proud of being German" you'd be considered a right-wing nationalist or racist because of the past'. As indicated at the beginning of this article, successive German governments mediated the concept of nationhood through the dominant European agenda and Europe became a focal point for the organisation of the German educational system. As a result of Germany's ambivalent relationship with its past, some German youth at Goethe privileged local and regional identities but the majority of interviewees seemed to employ national-European hybrid identities.

\section{Discussion and conclusions}

This article raises important questions about the need to promote inclusive political and educational approaches, and about how to address notions of cultural insensitivity. As we saw earlier, the two schools promoted Europeanness rather than German national identities, albeit with different emphases. The teachers I interviewed at Goethe Gymnasium seemed to ally the concept of Europe with multiculturalism, whereas at Tannberg, education was more Eurocentric, with some teachers getting close to being Islamophobic. Because the European dimension was privileged over and above national and multicultural agendas, young people in both schools had relatively high levels of knowledge about Europe, particularly at Goethe Gymnasium, where students' privileged backgrounds allowed them to take part in school exchanges and to travel across Europe (as opposed to their predominantly working-class peers at Tannberg). Despite some of the teachers' comments, there were no obvious signs of Islamophobia amongst youth. Some Turkish students, particularly at Tannberg, were positioned as 'foreigners' and 'others' but, as a result of being born in Germany and being able to mediate low-level ethnic conflict through inter-ethnic friendships, they developed ethno-national (Turkish German or German Turkish) identities. In contrast, in an inclusive non-Eurocentric school environment, like Goethe Gymnasium, they not only engaged in national discourses but 
also thought of Europe as being part of their hybrid identities. While the German students I talked to in Tannberg Hauptschule mainly employed Swabian German identities, they privileged German European identities at Goethe Gymnasium. This suggests that the school policy approaches were a major factor affecting student identities. Social class was also importantfor instance, with regard to identification with Europe, although it was not possible within the scope of this largely qualitative research to determine the relative significance of each factor.

One of the implications of this study is the need for policy-makers and politicians to redefine Germany's Europeanised national identity in multicultural terms so as to include minority ethnic communities like the Turkish Muslims. The evidence in this article suggests that in an inclusive environment, like Goethe Gymnasium, young people develop national-European identities and thus emphasise the political dimension of hybridity. In contrast, in an exclusionary and arguably Eurocentric environment, like Tannberg Hauptschule, young people (and minority ethnic youth in particular) privilege the ethnic dimension (e.g. 'being Turkish') of their hybrid identities. In other words, if German policy-makers and educators want to improve societal integration and promote a common bond between the national majority and minority ethnic communities, then they need to ally notions of multiculturalism with the Europeanised national identity. A large majority of German and Turkish interviewees in my study also felt that integration and multiculturalism were compatible and that minority ethnic communities should integrate into the German society whilst also maintaining their culture, customs and traditions. This meant learning the German language and being able to obtain German citizenship on the one hand, and practising intercultural tolerance and mutual respect on the other. A transformed concept of national identity is thus as important in developing a unifying factor (an integrative device) as tackling socio-economic disadvantages and promoting an intercultural dimension in German schools (see Kultusministerkonferenz, 1996).

Another implication of this article, which relates to the above, is the need to combat cultural insensitivities and inequalities. We have seen that, on occasion, in Tannberg Hauptschule, teachers spoke German with a foreign accent to Turkish students while suddenly switching to accent-free German when speaking to a German student. It is also problematic that, after fifty years of migration, Germany still officially employs divisive terms such as 'foreigner' or 'foreign citizen' rather than acknowledging their hybrid identities as German Turks or Turkish Germans. In addition, the 2003 Programme for International Student Assessment (PISA) study showed that Germany had the highest correlation between social class and educational achievement compared with other industrialised nations (OECD, 2004). A follow-up study revealed that the difference in achievement between minority ethnic and native students was more pronounced in Germany than in almost any of the other countries covered by the study, with the gap between Turkish and German students reaching 120 score points, the equivalent of about three years of study (OECD, 2006). Indeed, as a result of the tripartite secondary school system (Hauptschule, Realschule and Gymnasium) in Baden-Württemberg and other federal states, a relatively large proportion of minority ethnic students (over $30 \%$ on average in 2006), particularly Turks, attend largely working-class Hauptschulen, whereas only a small minority 
(around 5\% on average in 2006) attend mainly middle-class Gymnasia. Several of the regional educational systems are thus not only socio-ethnically segregated but also academically selective, as students who wish to go to a Gymnasium need high grades. However, instead of sweeping statements such as 'abandoning the multi-track school system' per se (United Nations, 2007, pp. 13ff.), policy-makers and politicians might rather want to focus on the future role of Hauptschulen, where many (minority ethnic) students are doubly disadvantaged (lower qualifications, higher poverty). All stakeholders are thus presented with the challenge of developing responses to such ingrained insensitivities and inequalities.

\section{Acknowledgements}

I would like to thank Madeleine Arnot for the stimulating discussions and comments which helped inform this article. I also thank Lynne Chisholm for her advice during data analysis and interpretation; and the British Economic and Social Research Council, the Cambridge European Trust and Clare Hall College Cambridge for their financial contributions.

\section{Notes}

1. In 1978, the Standing Conference of the Ministers of Education (Kultusministerkonferenz, KMK) published the document 'Europe in the Classroom', which was the first attempt to determine how notions of Europe should be tackled in German schools. In 1990, the KMK published a revised version stating that the goal of education must be 'to awaken in young people the consciousness of a European identity' (KMK, 1990, emphasis added).

2. Ius sanguinis (citizenship by birth) was complemented by a conditioned ius solis (citizenship by territoriality). This legislation gave citizenship rights to children of foreigners born in Germany of parents where one parent has been resident in Germany for a minimum of eight years with an unlimited residence permit.

3. In 2001, for instance, senior members of the conservative Christian Democratic Union (CDU) demanded that every public person in Germany must confess to be proud of Germany. Arguably, these debates around notions of national pride (Nationalstolz) symbolise Germany's ongoing struggle with its past and national identity.

4. The term 'German' is used here to refer to the native youth. In Germany, nationality plays a much greater role with regard to group identification compared with other European countries, where collective identities range from policy-status identities (e.g. immigrés in France) to racial classifications (e.g. 'white' or 'black' in England).

\section{References}

Auernheimer, G. (1990) How black are the German Turks? Ethnicity, marginality and interethnic relations for young people of Turkish origin in the FRG, in: L. Chisholm, P. Büchner, H-H. Krüger \& P. Brown (Eds) Childhood, youth, and social change: a comparative perspective (Basingstoke, Falmer), 197-212.

Bade, K. J. (Ed.) (1993) Deutsche im Ausland, Fremde in Deutschland: Migration in Geschichte und Gegenwart [Germans abroad, foreigners in Germany: migration in past and present] (München, Beck).

Bade, K. J. (2000) The German hub: migration in history and the present, Deutschland Magazine on Politics, Culture, Business and Science, 6, 38-43. 
Bhabha, H. K. (1990) Nation and narration (London, Routledge).

Boos-Nünning, U. (1986) Die schulische Situation der zweiten Generation [The educational situation of the second generation], in: W. Meys \& F. en (Eds) Zukunft in der Bundesrepublik oder Zukunft in der Türkei [Future in Germany or future in Turkey] (Frankfurt, Dagyeli Verlag), 131-144.

Butler, J. (1997) The psychic life of power: theories in subjection (Stanford, CA, Stanford University Press).

Caglar, A. S. (1997) Hyphenated identities and the limits of 'culture', in: T. Modood \& P. Werbner (Eds) The politics of multiculturalism in the New Europe: racism, identity and community (London, Zed Books), 169-185.

Council of Ministers of Education (1988) Resolution of the Council and the Ministers of Education: meeting within the Council on the European dimension in education of 24 May 1988, 88/C/177/02, Official Journal of the European Communities, C 177/5.

Dolby, N. E. (2001) Constructing race: youth, identity, and popular culture in South Africa (Albany, State University of New York Press).

Erdenir, B. (2006) Limits of Pax Europa: Muslimophobia. Available online at: www.eliamep.gr/ eliamep/files/Edrenir_Limits_Pax_Europea.pdf (accessed 30 March 2007).

Faas, D. (2007) Youth, Europe and the nation: the political knowledge, interests and identities of the new generation of European youth, Journal of Youth Studies, 2, 161-181.

Faas, D. (2008) Constructing identities: the ethno-national and nationalistic identities of white and Turkish students in two English secondary schools, British Journal of Sociology of Education, 1, 37-48.

Faist, T. (1993) From school to work: public policy and underclass formation among young Turks in Germany during the 1980s, International Migration Review, 2, 307-331.

Foucault, M. (1988) Technologies of the self, in: L. Martin, H. Gutman \& P. Hutton (Eds) Technologies of the self: a seminar with Michel Foucault (London, Tavistock), 16-49.

Gallo, G., Seifert, W. \& Strozza, S. (2002) Immigrants in the German labour market: the case of Italians, Greeks, former Yugoslavs and Turks, Migration Studies, 39, 755-793.

Goetz, K. (1996) Integration policy in a Europeanised state: Germany and the intergovernmental conference, Journal of European Public Policy, 1, 23-44.

Hall, S. (1992) New ethnicities, in: J. Donald \& A. Rattansi (Eds) 'Race', culture and difference (London, Sage), 252-259.

Hoff, G. R. (1995) Multicultural education in Germany: historical development and current status, in: J. A. Banks (Ed.) Handbook of research on multicultural education (New York, Macmillan), 821-838.

International Crisis Group (2007) Islam and identity in Germany. Available online at: www. crisisgroup.org/library/documents/europe/181_islam_in_germany.pdf (accessed 15 March 2007).

Katzenstein, P. J. (1997) United Germany in an integrating Europe, in: P. J. Katzenstein (Ed.) Tamed power: Germany in Europe (Ithaca, NY, Cornell University Press), 1-48.

Kultusministerkonferenz (KMK) (1990) Europa im Unterricht: Beschluss der Kultusministerkonferenz vom 08.06.1978 in der Fassung vom 07.12.1990 [Europe in the classroom: resolution of the Standing Conference of the Ministers of Education and Cultural Affairs of the States in Germany of 08.06.1978 in the version of 07.12.1990]. Available online at: www.bebis.cidsnet.de/faecher/ feld/europa/unterricht_dateien/kmkeuropa.htm (accessed 26 May 2006).

Kultusministerkonferenz (KMK) (1996) Interkulturelle Bildung und Erziehung in der Schule: Beschluss der Kultusministerkonferenz vom 25.10.1996 [Intercultural education at school: resolution of the Standing Conference of the Ministers of Education and Cultural Affairs of the States in Germany of 25.10.1996]. 
Available online at: www.bebis.cidsnet.de/faecher/feld/interkultur/rechtindex.html (accessed 11 September 2006).

Landeshauptstadt Stuttgart (Ed.) (2001) A pact for integration: the Stuttgart experience. Available online at: www.stuttgart.de/sde/global/images/sde_publikationen/s-ip/a_pact_for_integration.pdf (accessed 29 October 2006).

Landesinstitut für Schulentwicklung (2006) Schulgesetz für Baden-Württemberg [School law of BadenWürttemberg]. Available online at: www.leu.bw.schule.de/bild/SchG.pdf (accessed 22 March 2007).

Luchtenberg, S. (1997) Stages in multicultural theory and practice in Germany, in: R. J. Watts \& J. Jerzy (Eds) Cultural democracy and ethnic pluralism: multicultural and multilingual policies in education (Frankfurt am Main, Lang), 125-148.

Mac an Ghaill, M. (1999) Contemporary racisms and ethnicities: social and cultural transformations (Buckingham, Open University Press).

Mercer, K. (2000) A sociography of diaspora, in: P. Gilroy, L. Grossberg \& A. McRobbie (Eds) Without guarantees: in honour of Stuart Hall (London, Verso), 233-244.

Organisation for Economic Cooperation and Development (OECD) (2004) Learning for tomorrow's world: first results from PISA 2003 (Paris, OECD).

Organisation for Economic Cooperation and Development (OECD) (2006) Where immigrant students succeed: a comparative review of performance and engagement in PISA 2003 (Paris, OECD).

Rassool, N. (1999) Flexible identities: exploring race and gender issues among a group of immigrant students in an inner-city comprehensive school, British Journal of Sociology of Education, 1, 23-36.

Rippert, U. (2001) Stolz auf Deutschland: eine absurde Debatte [Pride in Germany: an absurd debate]. Available online at: www.wsws.org/de/2001/apr2001/stol-a11.shtml (accessed 23 March 2007).

Risse, T. \& Engelmann-Martin, D. (2002) Identity politics and European integration: the case of Germany, in: A. Pagden (Ed.) The idea of Europe: from antiquity to the European Union (Cambridge, Cambridge University Press), 287-316.

Santel, B. \& Weber, A. (2000) Zwischen Ausländerpolitik und Einwanderungspolitik: Migrationsund Ausländerrecht in Deutschland [Between foreigner politics and immigration politics: migration law and foreigner law in Germany], in: K. J. Bade and R. Münz (Eds) Migrationsreport 2000 [Migration report 2000] (Bonn, Bundeszentrale für politische Bildung), 109-140.

Schiffauer, W. (2006) Enemies within the gates: the debate about the citizenship of Muslims in Germany, in: T. Modood, A. Triandafyllidou \& R. Zapata-Barrero (Eds) Multiculturalism, Muslims and citizenship (London, Routledge), 94-116.

Şen, F. (2002) The Turkish minority in Germany, Informationen zur politischen Bildung, 277, 53- 62.

Şen, F. \& Goldberg, A. (1994) Türken in Deutschland: Leben zwischen zwei Kulturen [Turks in Germany: life between two cultures] (München, Verlag C. H. Beck).

Skeggs, B. (1997) Formations of class and gender: becoming respectable (London, Sage).

Soysal, Y., Bertilotti, T. \& Mannitz, S. (2005) Projections of identity in French and German history and civics textbooks, in: H. Schissler \& Y. Soysal (Eds) The nation, Europe and the world (Oxford, Berghahn Books), 13-34.

Tizard, B. \& Phoenix, A. (2002) Black, white or mixed race? Race and racism in the lives of young people of mixed parentage (London, Routledge).

United Nations (2007) Report of the Special Rapporteur on the right to education, Vernor Muñoz, on his mission to Germany. Available online at: www.netzwerk-bildungsfreiheit.de/pdf/Munoz Mission_on_Germany.pdf (accessed 23 March 2007). 